Милица М. МУСТУР*

Институт за књижевност и уметност Београд
Оригинални научни рад

Примљен: 11. 12. 2019.

Прихваћен: 12. 02. 2020.

\title{
ИЗМЕЂУ ИСТОРИЈЕ И МЕТАФИЗИКЕ - ЛЕКСИКОНСКА ФОРМА ХАЗАРСКОГ РЕЧНИКА И КУЛТУРНО ПАМЋЕЊЕ ${ }^{* *}$
}

Роман Хазарски речник Милорада Павића биће у овом раду разматран са становишта поетике културе и културног памћења. У Хазарском речнику Павић активира нека од најснажнијих места сећања српске културе, која у интерпретацији француског теоретичара Пјера Норе нису само просторно-географске одреднице, већ чворишни феномени који формирају најдубље идентитетске основе једне културне заједнице. Како је прозни имагинаријум Хазарског речника испуњен и местима сећањ $а$ двеју других култура, хебрејске и исламске, и њиховом тројном испреплетеношћу, Павић паралелно гради два наратива у оквиру назначене поетике културе: један „реинтегративни”, о снази и значају потиснутих културних фундамената појединачне (српске) културе, и један „интегративни” или „интегрални" о Култури као архифеномену који надилази како границе етнокултуролошке појединачности, тако и границе времена и простора. У раду се полази од претпоставке да је управо лексиконска структура Хазарског речника естетски најубедљивија форма у којој се може остварити поетика културног сећања. Другим речима, поетика енциклопедијске свеобухватности идеално подржава поетику културног памћења. Поред тога, тумачење Хазарског речника са становишта теорије места сећања показује се као интерпретативна спона која може да премости јаз између два релевантна, а опозитна тумачења романа, „историјског” и „метафизичког”.

Кључне речи: Милорад Павић, Хазарски речник, култура, места сећања, поетика културног памћења, лексиконска форма, Кристијан Олах, Предраг Палавестра.

Хазарски речник Милорада Павића једно је од најзагонетнијих дела српске књижевности новијег доба. Тридесет и пет година након објављивања и непребројивих критичких текстова, приказа, огледа и монографија посвећених овом роману стиче се утисак да његова енигма и даље није решена на сасвим задовољавајући начин. Када је у самом Хазарском речнику Павић

${ }^{*}$ mima_p@gmx.at

** Рад је резултат истраживања на пројекту Културолошке књижевне теорије и српска књижевна критика (бр. 178013), који финансира Министарство просвете, науке и технолошког развоја Републике Србије. 
аутопоетички експлицитно промовисао неисцрпност интерпретација свог романа, он је, разуме се, предвидео и могућност дијаметрално супротстављених тумачења. Она су се заиста и појавила, а Хазарски речник је тиме само подигао свој рејтинг као првак енигматичности међу ремек-делима српске књижевности, јер су се поједине опозитне интерпретације показале подједнако уверљивим. У преко три деценије дугој историји рецепције овог романа могу се издвојити две интерпретације које иду у ред најрелевантнијих тумачења, а истовремено чине један „идеалан” антиномијски пар. Прва је настала релативно брзо након објављивања Хазарског речника 1984. из пера Предрага Палавестре (в. Палавестра 1991: 238-263), друга скоро три деценије након тога, 2012. године, од руке младог Кристијана Олаха (в. Олах 2012). Као на познатој Рафаеловој фресци „Атинска школа”, где два филозофска титана, Платон и Аристотел, показују у различитим правцима, први ка небу и царству идеја, други ка земљи и свету етичких принципа, наглашавајући тако сопствена филозофска и аксиолошка опредељења, и два наведена тумачења Хазарског речника дају хоризонталну и вертикалну интерпретацију романа.

Предраг Палавестра у огледу „Чаролије Милорада Павића” усмерава тумачење на топос цивилизацијског ишчезнућа народа, реализован у теми о нестанку Хазара са историјске мапе света и нуди прву, а касније веома популарну алегоријску интерпретацију Хазарског речника као наратива о историјској судбини Срба, повлачећи директну паралелу између хазарског и српског историјског усуда.

Кристијан Олах се у монографији Кюига-Бог оглашава са у нашој науци о књижевности неконвенционалне позиције (православне) теолошке књижевне мисли. У фокусу Олахове студије, до сада најобимније и најтемељније интегралне интерпретације Павићевог романа, стоји филозофско-метафизички формулисано питање истине као тема од највишег значаја за разумевање Хазарског речника. Према Олаху, Павић у фокус свог дела поставља проблематику онтолошког устројства света, диференције између историјске и метафизичке истине, као и епистемолошка питања о могућности сазнавања истине и долази до закључка да Хазарски речник формулише једну врсту ЊуЕјџ духовности, компатибилну са духовним сензибилитетом постмодерног доба, духовност арбитрарности истине, која је уједно и спиритуалност без Бога.

Можда не постоји приступ Хазарском речнику који би могао да помири тумачења са две крајње позиције, једне усмерене на историју, друге на метафизику и тиме на метаисторију, једне заокупљене овоземаљским, друге загледане у онострано. Али, може бити да постоји треће становиште које би се у односу на остала два показало комплементарним и тиме их, као у извесном смислу средишње, на пола пута између историјског и надисторијског, између физичког и метафизичког, приближило бар до оне мере у којој три књиге Хазарског речника - Црвена, Жута и Зелена - истовремено симболизују самосталне, али и једне на друге усмерене светове.

Таква трећа позиција отвара се анализом Павићевог романа-лексикона са становишта поетике културног памћења. Пројекција Хазарског речника 
као архива културног сећања, покреће низ питања. Није ли Павић у овом роману назначио драму културног идентитета за коју се испоставило да је данас још актуелнија него у време настанка романа? Драму која није зла привилегија само српског народа у актуелном историјском тренутку, када се у вртлогу глобализације трансформишу традиционалне културне и идентитетске схеме, већ представља потрес најширих размера, изазов за сваког појединца и за сваку културну заједницу, од тзв. маргиналне до тзв. већинске? Какав је удео енциклопедијског предлошка у грађењу Павићеве културолошке поетике? На крају, у чему може бити смисао овакве поетичке оријентације - је ли он чисто дескриптиван, декларативан или имплицитно садржи и апелативни тон, усмерен на читаочеву културну свест, или, чак, његов културни ангажман?

Пре одговора на ова питања треба истаћи да Хазарски речник тематизује културу и као историјски и као надисторијски, па чак и метафизички феномен. Роман активира нека од најснажнијих места сећањ $а$ српске културе, али и слику Културе као архифеномена који надилази и границе етничке појединачности и границе времена и простора.

Синтагма места сећања ушла је у употребу средином осамдесетих година прошлог века преко француског теоретичара Пјера Норе као ознака за нов правац у оквиру научне историографије (в. Nora 1984, 1986, 1992). Чим се појавио, термин је - у француском оригиналу lieu de mémoire - издигнут у ранг нове истраживачке парадигме од универзалног значаја. Са овим појмом Нора везује представу о томе да се колективно сећање једне друштвене групе (за њега је то по правилу француска нација) кристалише на одређеним местима. Сам термин не означава (нужно) просторно-географску одредницу, већ феномен од врхунског симболичког значаја за формирање идентитета једне културне заједнице и обликовање културе сећањ $а$. У свом оригиналном контексту, у тротомном зборнику који је приредио Пјер Нора, појам места сећања имао је понешто песимистичан призвук у вези са представом о чврстом националном идентитету. Ауторово полазиште јесте увид у разарање концепта националне државе на крају 20. века, њеним растакањем у веће (Европа, „Запад”) или мање (регион/област, породица) целине. Нуспроизвод те дезинтеграције је према Нори губитак националног оквира колективног памћења, чему увелико доприноси одсуство великих историјских догађаја попут Првог или Другог светског рата, са њиховом снагом да конституишу наративе који једну нацију уједињују у заједничком сећању. Са њиховим нестанком, нестале су и сасвим одређене друштвене групе (миљеи) као носиоци историјског памћења, па тако миљеи сећаға уступају позорницу местима сећања. Чини се да је носећа идеја овог концепта укидање основа за историографију базирану на континуитету историјског памћења: одустаје се од историографског метода засновног на друштвеној и политичкој историји, на континуитетима, тј. сукцесивном смењивању политичких и друштвених феномена. Уместо тога, историографија се поново приближава концепту Ideengeschichte, историји идеја.

Из историографског домена појам место сећања преселио се на поље хуманистичких наука, где је као нова истраживачка платформа подстакао 
дискусију о целом комплексу питања везаних за проучавање културе у науци о књижевности: како се колективно памћење, и култура памћења и заборава јављају као топоси књижевности, али и како сама књижевност, у виду целих жанрова или појединачних дела, може да задобије статус места сећања. (Тако je, на пример, у француском контексту за једно од књижевних места сећања проглашен роман Марсела Пруста У трагању за изгубљеним временом).

Узимајући у обзир „историјску” и „метафизичку” интерпретацију $P e$ чника, са становишта њихових доминантних закључака, постављају се следећа питања: Да ли је могуће да је симболичка топологија Хазарског речни$\kappa a$, са својим референцама на огроман број места сећања српске историје и културе од Средњег века до савременог доба, само декор? Јесу ли Балкан, Средња Европа, Византијско царство, Косово, Ердељ, Панонија, Подунавље, Поморавље, Херцеговина, Моравска, Влашка, Словачка, Анадолија, Крим, Москва, Цариград, Солун, Атос, Једрене, Беч, Дубровник, Београд, Земун, Нови Сад, Даљ, Рим, Венеција, Пешта, Столни Београд, Ћирило и Методије, Дунав, Црно море, лоза Бранковића, топос сеоба и бројни манастири и задужбине српских владара и властеле - да ли је све то мање-више занемарљива кулиса пред којом се одиграва радња од суштинског значаја за интерпретацију овог романа, радња која Хазарски речник смешта искључиво у домен филозофије и метафизике, у свет идеја? Да ли је, обрнуто, довољно констатовати паралеле између српског и хазарског историјског хода, побројати места сећања српске културе да би се роман прочитао као алегорија на српски усуд у југословенском историјском пројекту, занемарујући у потпуности метафизичко-филозофски слој романа?

Питања су, наравно, реторичка. Не, цео набројани паноптикум симболичких места није само украс на поетичком здању Хазарског речника, већ један од његових носећих стубова. У српској књижевној критици је овај културолошки набој Павићевог дела већ одавно регистрован и описан у многим од својих аспеката. У радовима критике доминирају два вида Павићевог приступа култури: један који захвата у њену дубину и један који обухвата ширину њеног распростирања. Радови који описују Павићево дубинско културолошко сондирање груписани су око идеје да се ауторово дело поетички ослања на симболику културног (и уже књижевног) палимпсеста; Павић захвата дубоко у стратификацијске слојеве културе и бележи смењивање њених стадијума кроз епохе откривајући палимпсестне трагове прошлог у садашњем. На другој страни, Павић је по увидима критике страствено заокупљен експанзијом културних феномена по различитим географским меридијанима и временским димензијама и њиховим повезивањем кроз суспензију просторних и временских дистанци у маниру фантастичког фабулирања.

Говор о местима сећања у Хазарском речнику подстакнут је намером да се овој дебати дода још једна допунска димензија, која би ову аналитичку линију у идеалном случају још продубила. У мноштву изречених судова о статусу културе у Павићевом делу, тумачење ослоњено на симболичку снагу места сећања надовезује се најпре на тематику културног идентитета. Тако Александар Јерков, пишући о топосу Медитерана у Павићевим Медитеран- 
ским причама, обухвата и палимпсестне и „експанзијске” манифестације онога што експлицитно именује као једну врсту пишчеве „културне поетике” (Јерков 1994: 165), ${ }^{1}$ а када у предговору овој збирци констатује како „Павић прати културне и цивилизацијске просторе који су обележили судбину Срба, што његовим необичним заплетима, неспутаној фантазији и згуснутом стилу обезбеђује корене историјског и духовног саморазумевања" (Јерков 1994: 164), он је већ на корак од интерпретације у светлу теорије lieu de mémoire.

Да би се схватио допринос идеје места сећања културолошким анализама Хазарског речника, треба се још једном накратко осврнути на главну премису нове историографске концепције Пјера Норе и његових сарадника. Вреди се запитати не постиже ли промена научне парадигме коју уводи Нора циљ супротан прокламованом? Није ли, наиме, историографија утемељена на симболичким местима сећања једне националне заједнице уместо на минуциозном описивању њених политичко-историјских токова заправо много солидније тло за изградњу националног културног идентитета, поузданији гарант његове (ре)афирмације? Није ли таква историографија већ закорачила у област (националног) мита и легенде, издвајајући из бескрајног фактографског корпуса појаве, личности и догађаје врхунског симболичког набоја, придајући им тако статус митског трајања и валидност надвремених феномена? Павићев Хазарски речник са својим узношењем историографског у области мита и фантастике, са својим реферисањем на места сећања српске историје и културе, али и са својом лексиконском формом као књижевним отелотворењем архива културе изграђује поетику културног памћења која испуњава управо тај несвесно призвани циљ „нове” историографије. Другим речима, књижевно дело постаје, ретко где тако експлицитно и уверљиво као у Хазарском речнику, енциклопедија места сећања једне културе. Отуда Хaзарски речник репрезентује један специфичан и аутентичан вид „параисториографске" поетике, која можда и постоји једино у Павићевим делима. У њој се укрштају два на први поглед некомпатибилна односа према културној историји (и историографији као њеном писменом сведочанству), јер Хазарски речник у духу „класичне” историјске метафикције сведочи непоузданост дефинитивног историјског (са)знања, док се истовремено у својој функцији енциклопедије симболичких места српске културе сам презентује као форма врхунске артикулације културноисторијске свести. Овако сагледана, културна поетика Хазарског речника као да на идеалан начин излази у сусрет лиотаровском концепту постмодерне, по коме једно дело, да би било модерно, мора претходно бити постмодерно. Управо зато су и два односа према историји само наизглед некомпатибилна: лиотаровска перманентна регенерација модерности у Хазарском речнику изведена је рушењем једног мита, мита о поузданости историографског дискурса, и устоличењем контра-мита о књижевном делу као новом, истинскијем складишту културне историје.

\footnotetext{
${ }^{1}$ Културолошка парадигма као поетичка детерминанта Павићевог дела у целини, исцрпно је описана у Јерковљевој студији „Од нове текстуалности до културне поетике” (в. Јерков 1996).
} 
Нека од места сећања у Хазарском речнику јесу и дословно места, географске тачке на мапи српске културе. Погледа усмереног на историјску везаност Срба за Византију, незамисливо је да учестало призивање Цариграда у Хазарском речнику може служити декоративној сврси. Напротив, стално реферисање на Константинопољ као на позорницу кључних догађаја у причи о Хазарима призива византијски топос у свест читаоца као место снажног симболичког набоја у културној историји Срба. У „Црвеној књизи” иницијатива за учешће у хазарској полемици, централном догађају Речника, долази са цариградског двора. Грчки цар, глава византијског царства, као свог изасланика за учешће у верском спору бира Константина Философа, то јест светог Ћирила. Цариград је тако за источно хришћанство место са ког се у свет шаље посланица о истинитој вери. Цариград је посредно и место одакле се одлучује о бити или не бити једног народа, Хазара. Павићев Хазарски речник фиксира Цариград као фундаментално место сећања српске културе, а сам Цариград фигурише као симбол византијског жига утиснутог на културни идентитет Срба у окриљу источног хришћанства.

Већ споменути Константин Солунски, то јест Константин Философ, или, у српској културној свести, једноставно - Ћирило, заједно са братом Методијем спада међу најважније фигуре прозног света Хазарског речника. Када Павић у маниру магичног реализма описује деловање солунске браће, он ћирилометодијевску традицију приказује као conditio sine qua non српске културе, чији би лик у одсуству ових скоро митских историјских фигура био неки потпуно други. И сасвим је у складу са поетиком културног памћења, када Павић у Хазарском речнику не извлачи у први план верску мисију Ћирила и Методија, већ са истим поетским замахом оживљава њихову културну мисију међу Словенима, а тако и међу Србима.

Можда се још јаснија слика о врсти Павићевог културолошког ероса добија када схватимо да он симболичким местима не сматра само феномене исписане највећим словима у званичној историографији. Не, са осетним задовољством у културном контексту Павић открива стратификацијске слојеве културе и истиче везе између места сећања велике симболичке тежине и оних која нису тако снажно урезана у колективну свест. Споне те врсте Павић приказује у фантастичком маниру, као када се за једног од главних јунака Речника, Аврама Бранковића, каже да је дао да се у Цариграду „сазида тачно половина цркве посвећене мајци Ангелини, његовој чукунбаби коју је источна црква прогласила светицом, док се друга половина исте цркве налази у Ердељу, у постојбини Бранковићева оца" (Павић 1984: 30). Места попут ових имају јак апелативни потенцијал да приближе тополошке одреднице, које нису удаљене само просторно, него и по степену њихове тежине у колективној културној свести. Ердељ у тој свести није исто што и Цариград, и сигурно је да такав статус није неоправдан. Па ипак, као постојбина властелинске породице Бранковић, Ердељ (или Трансилванија) и те како има своје место у историји српске културе. Можда би управо Бранковићи као позната владарска породица, као ктитори српских манастира у Румунији, могли бити симбол српског присуства у тим областима, у којима је простор између Теми- 
швара и Дунава већ у 16. веку називан „Српском земљом”. Када Павић само једним потезом фантастичког фабулирања премости географску дистанцу између Цариграда и Ердеља, он тиме истовремено освешћује различите аспекте културе сећања. Он указује на географску ширину српског културног простора, то јест, на крајње границе распростирања те културе; на условну фрагментарисаност културе као последице њеног историјског фатума, обележеног сеобама и променама културних средишта; на невидљиве, недовољно освешћене или заборављене спојнице између места сећања неуједначеног симболичког значаја. Самим тим, Павић користи простор књижевног текста не само као простор обнове културног памћења, већ и као простор његовог креирања. Знатно израженије него у традиционалном историјском роману, књижевност је овде у улози пара-историографског жанра, у чијој је моћи да пружи своју сопствену визију културног идентитета, делујући мнемонички, стабилизујуће и корективно, у потпуној слободи наспрам званичне историографије према којој може да се заузме читав низ различитих позиција - од валидације до анархично-разиграног негирања.

Како је речено, и сама књижевност, у виду целих жанрова или појединачних дела, може да задобије статус места сећања. Ако је за француску културу то Прустов роман, а за немачку Гетеов Фаусm (в. François, Schulze 2001), онда је према Павићу једно од књижевних симболичких места српске културе Рјечник Вука Караџића, који је, по давно установљеном консензусу књижевне критике, безмало митски интертекстуални претходник Хазарског речника. По тим увидима, Вуков Српски рјечник фигурише као литерарни предложак Павићевог романа због наративне „надоградње” која од њега чини више од речника и представља једну врсту енциклопедије српског народног живота.

Свет Хазарског речника не апелује само на колективно памћење и културну симболику Срба. Култура у њему има статус историјског, али и надисторијског, па чак и метафизичког феномена, који се рађа у преплету места̂ сећања Хришћанства, Јудаизма и Ислама. Тако Павић паралелно гради два наратива у оквиру назначене поетике: један „реинтегративни”, о симболичкој тежини фундамената српске културе, и један „интегративни” или „интегрални" о Култури као архифеномену који надилази и границе времена и простора и границе етнокултуролошке и верске посебности. Илустрације ради, довољно је сетити се односа између три фигуре барокног слоја романа, Аврама Бранковића, Самуела Коена и Јусуфа Масудија, ловаца на снове, чији се заједнички напори на прибављању свих делова изгубљеног „Хазарског речника" одвијају у знаку агапеовски схваћене повезаности и у чијем тријадном односу Самуел Коен и Аврам Бранковић сањају јаву оног другог, док Јусуф Масуди има моћ да пребива у њиховим сновима.

Лексиконска структура Хазарског речника при томе је естетски најубедљивија форма у којој се остварује поетика културног сећања. Ако је енциклопедијска форма метафора текстуалног архива, симбол ризнице културе и отеловљење идеала интегралности, читалац Хазарског речника позван је да захвати у тај архив сећања и да из њега извуче на површину чворишне културне симболе, да пронађе елементе које их повезују и спајају у интеграл- 
ну целину. Другим речима, поетика „енциклопедијск[е] свеобухватност[и]” (Јерков 1996: 131) идеално подржава поетику културног памћења. Али, управо лексиконска форма у којој су сржни елементи културе разбијени и расути у фрагменте, говори да интегралност културе није никаква датост. Напротив, интегралност културе захтева будност сталног преиспитивања, сталну жељу за повезивањем места сећањ а у јединствену културу сећања.

Шта нам, гледајући из ове перспективе, Павић саопштава када мистификаторски апелује на нас као читаоце да повежемо речничке одреднице у „правилном редоследу”? Постоји ли „правилан редослед” читања у једној енциклопедији? Или је правилност редоследа метонимија за нешто друго? Да ли Хазарски речник заправо указује на могућност или нужност да се делује у правцу супротном од оног којим су према легенди кренули Хазари, када су се одрекли своје вере, а тиме очигледно и своје културе и тако закорачили на пут своје пропасти? Да ли Хазарски речник ипак није грандиозни реквијем над српском културом, злослутни опис нестајања, већ апел да, како рационално тако и песнички предано, освестимо своја места сећања и пронађемо њихове спојнице, не би ли нас у свету хиперглобализације мимоишла хазарска судбина ишчезнућа са мапе светске историје? Павић не оставља само могућност да се не предамо фатализму Хазара, већ нас његова реверзибилна књижевност упућује на реверзибилност књиге Историје, на снагу Историје, на запретене силе које нису само лавиринтски деструктивне, већ и живоносно колоритне, магијски сањиве.

Поред свега наведеног, поглед на Хазарски речник из перспективе места сећања указује и на један могући компромис између метафизичке и историјске интерпретације романа. Вратимо се, са ове позиције, његовом тумачењу из метафизичког херменеутичког угла. Како је показао Кристијан Олах, амбиција је хазарских ловаца на снове да се прикупљањем „снова” свих људи, то јест епифанијских тренутака њихових живота, и сабирањем тих снова у „хазарске речнике” наново отелотвори изгубљени „Хазарски речник”, и тако поново створи свет, али „на бољи начин”. Тиме би било поново оваплоћено мистично тело праоца Адама као знак савршеног онтолошког устројства света.

Шта, међутим, може да сугерише аналогија између покушаја ловаца на снове да прикупе епифанијске тренутке свих људи у „хазарске речнике” и романескне структуре и наслова Павићевог романа Хазарски речник? Ако писац Милорад Павић сачини роман по имену Хазарски речник, који тематизује састављање изгубљеног „Хазарског речника” издавача Даубмануса, то јест покушаје ловаца на снове да сачине бројне „хазарске речнике”, онда се јасно открива метафорички смисао састављања „Хазарског речника” или „хазарских речника" као чина писања или, уопштено, као културног чина, који има моћ да, метафорички „поново створи свет, али на бољи начин.” Своју поетичку заводљивост Хазарски речник црпи управо из своје високо семантизоване структуре. То је роман чија је структура уједно врхунски израз онога што сам роман садржи као своју централну тему.

Пројекат поновног састављања „Хазарског речника” се у оквиру романа испоставља као утопијски, јер прикупљање свих делова првобитног „Хазар- 
ског речника" и тиме мистичног Адамовог тела, тј. онтолошког устројства света у тренутку његовог савршенства, ометају демонске силе трију монотеистичких религија.

Али, иако је карактер пројекта стварања бољег онтолошког поретка у оквирима света романа утопијски, Хазарски речник на најмање два начина нуди и могућност оптимистичког разрешења хазарске потраге са уцеловљењем. Поред метафоричког смисла састављања „хазарских речника” као чина писања или, уопштено, као културног чина, Павић експлицитним аутопоетичким коментарима указује на стварност изван фиктивног света романа: Сугеришући читаоцу да и сам настави пројекат састављања „Хазарског речника" по свом редоследу и по сопственом науму, он га заправо упућује на откривање онога што се у самом роману назива „тренуцима највише просветљености", а што се изван мапе Хазарског речника може поистоветити са стварањем културних чинова, са освешћивањем и креирањем нових места сећања једне културе, тј. Културе. Павић апелује на читаоца да и сам ствара нова симболичка места које култури/Култури обезбеђују сигурност историјског трајања и митски, можда чак и метафизички квалитет. На нивоу индивидуалне егзистенције он наводи читаоца да настави са стварањем сnоменика, рукотворних и нерукотворних, „надмудри” своје чисто историјско биће и завири у области духовног постојања.

\section{ЛИТЕРАТУРА}

Јерков 1994: А. Јерков, „Палимпсести медитеранских култура”, у: Милорад Павић, Медитеранске приче (прир. Александар Јерков), Подгорица: Октоих, 163-179.

Јерков 1996: А. Јерков, „Од нове текстуалности до културне поетике”, у: Милорад Павић, Заувек и дан више. Сабрана дела М. Павића, Београд: Драганић, 111-180.

Олах 2012: К. Олах, Кюига-Бог. (Постмодерна) духовност у Хазарском речнику Милорада Павића, Београд: Институт за књижевност и уметност.

Павић 1984: М. Павић, Хазарски речник, Београд: Просвета.

Палавестра 1991: П. Палавестра, Книжевност - критика идеологије, Београд: Српска књижевна задруга.

Селимовић 1968: М. Селимовић, „За и против Вука”, у: О Вуку Караџићу, Београд: Просвета, 105-122.

Nora 1984, 1986, 1992: P. Nora (sous la direction de), Les Lieux de mémoire, 3 tomes: t. 1 La République (1 vol., 1984), t. 2 La Nation (3 vol., 1986), t. 3 Les France (3 vol., 1992) Paris: Gallimard (Bibliothèque illustrée des histoires).

François, Schulze 2001: É. François, H. Schulze (Hrsg.): Deutsche Erinnerungsorte, 3 Bände, München: Beck. 


\section{Milica M. Mustur \\ ZWISCHEN GESCHICHTE UND METAPHYSIK - DIE LEXIKONFORM DES CHASARISCHEN WÖRTERBUCHS UND KULTURELLES GEDÄCHTNIS}

\section{(Zusammenfasssung)}

Der Roman Das Chasarische Wörterbuch von Milorad Pavić wird in dieser Arbeit vom Standpunkt der Kulturpoetik und des kulturellen Gedächtnisses untersucht. Im Chasarischen Wörterbuch aktiviert Pavić einige der symbolisch wichtigsten Erinnerungsorte serbischer Kultur. Innerhalb seiner Kulturpoetik entfaltet Pavić parallell zwei Narrative - ein „,reintegratives” über die Bedeutung von Kulturfundamenten einer einzelnen (der serbischen) Kultur und ein ,integratives” bzw. ,,integrales” über Kultur als Archiphänomen, das sowohl ethnokulturelle als auch raumzeitliche Grenzen überschreitet. In der Arbeit wird davon ausgegangen, dass gerade die lexikalische Struktur des Chasarischen Wörterbuchs die ästhetisch wirkungsvollste Form für die Realisierung der Poetik des kulturellen Gedächnisses ist. Mit anderen Worten - die Poetik enzyklopädischer Integralität unterstützt die Poetik des Kulturgedächtnisses auf ideale Weise. 